\title{
Peran Orang Tua Dalam Pendidikan Anak Selama Pembelajaran Daring Di Masa Pandemi Covid -19 Di Desa Garot Cut Kecamatan Indra Jaya Kabupaten Pidie
}

\author{
Basri, Nurdiana \\ Univeraitas Jabal Ghafur \\ Jalan Garot -Sigli Kecamatan Indra Jaya Kabupaten Pidie Nanggroe Aceh Darussalam

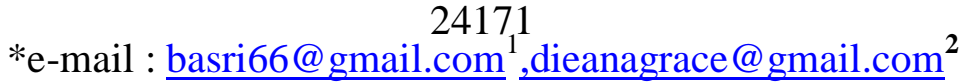

\begin{abstract}
Currently, many families are confused with educational problems as a result of Covid-19, because the family is the first and foremost institution in educating, protecting and nurturing their children in accordance with family values, religious values, so it can be said that the family is a milestone. children's first in knowing the world. The principle of education policy during the Covid-19 pandemic is to prioritize the health and safety of students, educators, education staff, families, and society in general, as well as considering the growth and development of students and psychosocial conditions in an effort to fulfill educational services during the Covid-19 pandemic. The government has issued various policies and initiatives to deal with learning obstacles during the Covid-19 pandemic, such as the revision of the Joint Decree (SKB) of the Four Ministers which was issued on August 7, 2020, to adjust learning policies in the current pandemic era. In addition, schools are given the flexibility to choose a curriculum that suits the learning needs of students during the pandemic, as stipulated in the Decree of the Minister of Education and Culture regarding the curriculum during an emergency. In connection with the above phenomenon, parents in Garot Cut Village who are too busy with their work pay less attention and lack of understanding in playing their role in children's education, so that parents think that the role of education is more for teachers in schools than their parents. Based on the evaluation and simulation on training from community service activities, it can be seen that with the training, the role of parents in creating the use of the internet for education is still very rarely done. . In addition, the service program presented adds insight for parents how the role of parents and teachers in building children's habits to use the internet for learning has not been carried out. The role of parents and teachers is very important, because they are people who deal directly with children in the family environment and teacher schools.
\end{abstract}

\footnotetext{
ABSTRAK

Saat ini banyak keluarga yang dipusingkan dengan masalah pendidikan akibat dari Covid-19, karena keluarga adalah institusi pertama dan utama dalam mendidik, melindungi serta memelihara anak-anaknya sesuai dengan nilai-nilai
} 
Basri, Nurdiana

keluarga, nilai-nilai keagamaan, sehingga dapat dikatakan bahwa keluarga merupakan tonggak pertama anak dalam mengenal dunia. Prinsip kebijakan pendidikan di masa pandemi Covid-19 adalah mengutamakan kesehatan dan keselamatan peserta didik, pendidik, tenaga kependidikan, keluarga, dan masyarakat secara umum, serta mempertimbangkan tumbuh kembang peserta didik dan kondisi psikososial dalam upaya pemenuhan layanan pendidikan selama pandemi Covid-19, pemerintah telah mengeluarkan berbagai kebijakan dan inisiatif untuk menghadapi kendala pembelajaran di masa pandemi Covid-19, seperti revisi surat keputusan bersama (SKB) Empat Menteri yang telah diterbitkan tanggal 7 Agustus 2020, untuk menyesuaikan kebijakan pembelajaran di era pandemi saat ini. Selain itu, sekolah diberi fleksibilitas untuk memilih kurikulum yang sesuai dengan kebutuhan pembelajaran siswa di masa pandemi, sebagaimana ditetapkan dalam Keputusan Menteri Pendidikan dan Kebudayaan terkait kurikulum pada masa darurat. Bererkaitan dengan fenomena di atas para orang tua di Gampong Garot Cut yang terlalu sibuk dengan pekerjaannya kurang memperhatikan dan kurang memahami dalam memerankan perannya dalam pendidikan anak,sehingga para orang tua berpikir bahwa tugas pendidikan lebih berperan guru di sekolah ketimbang orang tuanya. Berdasarkan evaluasi dan simulasi pada pelatihan dari kegiatan pengabdian masyarakat dapat diketahui bahwa dengan adanya pelatihan maka peran orang tua dalam menciptakan pemanfaatan internet untuk pendidikan masih sangat jarang dilakukan. . Selain itu, program pengabdian yang dipaparkan menambah wawasan bagi para orang tua bagaimana peran orang tua dan guru dalam membangun kebiasaan anak untuk memanfaatkan internet untuk pembelajaran masih belum dilakukan. Peran orang tua dan guru ini sangat penting, karena mereka adalah orang yang berhadapan langsung dengan anak-anak dilingkungan keluarga dan sekolah guru.

\section{PENDAHULUAN}

Berbicara mengenai mendidik anak, orang tua merupakan orang yang bertanggung jawab dalam pendidikan Saat ini banyak keluarga yang dipusingkan dengan masalah pendidikan akibat dari Covid-19, karena keluarga adalah institusi pertama dan utama dalam mendidik, melindungi serta memelihara anak-anaknya sesuai dengan nilai-nilai keluarga, nilai-nilai keagamaan, sehingga dapat dikatakan bahwa keluarga merupakan tonggak pertama anak dalam mengenal dunia. Prinsip kebijakan pendidikan di masa pandemi Covid-19 adalah mengutamakan kesehatan dan keselamatan peserta didik, pendidik, tenaga kependidikan, keluarga, dan masyarakat secara umum, serta mempertimbangkan tumbuh kembang peserta didik dan kondisi psikososial dalam upaya pemenuhan layanan pendidikan selama pandemi Covid-19. Pemerintah telah mengeluarkan berbagai kebijakan dan inisiatif untuk menghadapi kendala pembelajaran di masa pandemi Covid-19, seperti revisi surat keputusan bersama (SKB) Empat Menteri yang telah diterbitkan tanggal 7 Agustus 2020, untuk menyesuaikan kebijakan pembelajaran di era pandemi saat ini. Selain itu, sekolah diberi fleksibilitas untuk memilih kurikulum yang sesuai dengan kebutuhan pembelajaran siswa di masa pandemi, sebagaimana ditetapkan dalam Keputusan Menteri Pendidikan dan Kebudayaan terkait kurikulum pada masa darurat. 
Para orang tua yang menentukan masa depan anak. Keluarga dan lingkungan adalah jalur pendidikan informal (UU No 20, 2003: 1). Di dalam keadaan yang normal, keluarga merupakan lingkungan pendidikan pertama dan utama bagi anak. Karena disanalah anak mulai mengalami proses sosialisasi awal, serta mengenal dunia sekitarnya, juga pola pergaulan hidup yang berlaku seharihari (Niecmah, 2016: 15). Menempuh jalur pendidikan formal juga menjadi salah satu upaya yang dilakukan orang tua untuk mengembangkan potensi-potensi alamiah yang dimiliki anak agar dapat diarahkan ke arah yang lebih baik lagi. Dalam hal ini, lembaga penyelenggara pendidikan formal adalah sekolah. Sejalan dengan pendidikan nasional yang bertujuan untuk mengembangkan potensi peserta didik menjadi manusia yang beriman dan bertakwa kepada Tuhan Yang Maha Esa, berakhlak mulia, sehat, berilmu, cakap, kreatif, mandiri, dan menjadi warga negara yang demokratis dan bertanggung jawab (UU No 20, 2003: 6).

Namun dalam mengakui keterbatasan dan peluang yang dimiliki, sehingga orang tua meminta pihak luar lain membantu mendidik anak anak mereka, pihak lainnya adalah guru di sekolah. Namun demikian, setelah anak-anak dititipkan di sekolah, orang tua tetap untuk bertanggung jawab untuk keberhasilan pendidikan a Seiring kemajuan teknologi informasi dan komunikasi, kini pendekatan pembelajaran telah berubah ke arah pembelajaran abad pengetahuan. Orang dapat belajar di mana saja, kapan saja, dengan siapa saja. Itulah ciri pembelajaran abad pengetahuan yang dikenal sebagai berbasis komputer (Kuntarto, 2017: 99). Internet sudah mempengaruhi hampir dalam semua aspek kehidupan manusia. Rasanya belum lama media seperti surat kabar, majalah, radio, dan televisi merupakan sumber informasi yang paling efektif. Realitas kini media seperti facebook, youtube, twitter, instagram, whatsapp, dan sejenisnya menjadi media komunikasi dan informasi yang paling digemari. Tempat perbelanjaan yang menawarkan berbagai fasilitas mewah, kini terancam gulung tikar akibat berkembangnya penjualan online. Alat transportasi umum ojek yang dulu dipandang sebelah mata, kini menjadi transportasi online yang trend bagi semua kalangan. Begitupun aspek kehidupan lainnya terus berkembang dan berinovasi sebagai akibat tuntutan perubahan zaman terutama teknologi internet (Chalim, 2018: 42).

Melihat kasus pandemi akibat virus corona (Covid-19). Pemerintah telah mengalihkan kegiatan pembelajaran dari sekolah ke rumah masing masing siswa sebagai bagian dari upaya menghentikan penyebaran virus corona (Covid-19). Agar tidak disalahartikan sebagai hari libur, maka proses kegiatan pembelajaran dilakukan secara online. Penggunaan media pembelajaran dalam proses belajar mengajar merupakan salah satu upaya untuk meningkatkan efektivitas serta kualitas proses pembelajaran yang pada akhirnya dapat meningkatkan kualitas hasil belajar siswa. Penggunaan media pembelajaran daring (online) sebagai media distance learning (pembelajaran jarak jauh) menciptakan paradigma baru apabila dibandingkan dengan pendidikan konvensional (Dewi, 2011: 4, Yuhasriati et al. 2020). Pembelajaran daring bertujuan memberikan layanan pembelajaran bermutu dalam jaringan (daring) yang bersifat masif dan terbuka untuk menjangkau peminat yang lebih banyak dan lebih luas (Sofyana, 2019: 82).

Berdasarkan fenomena di atas para orang tua di Gampong Garot Cut yang terlalu sibuk dengan pekerjaannya kurang memperhatikan dan kurang memahami dalam 
Basri, Nurdiana

memerankan perannya dalam pendidikan anak,sehingga para orang tua berpikir bahwa tugas pendidikan lebih berperan guru di sekolah ketimbang orang tuanya.

\section{METODE}

Pelaksanaan kegiatan pengabdian kepada masyarakat ini meliputi:

a) Tahap pendahuluan, pada tahap ini akan dipersiapkan surat ijin dengan pihak terkait, mempersiapkan tempat pelatihan, mempersiapkan materi, alat dan bahan.

b) Tahap sosialisasi dan audiensi, tahap ini dilakukan dengan cara mengumpulkan orang tua di Desa Garot Cut dan diberikan penjelasan mengenai pendekatan terhadap anak saat si anak mengikuti pembelajaran daring agar si anak dapat memahami mata pelajaran yang diberikan oleh gurunya.

c) Tahap pelaksanaan kegiatan pelatihan, tahap ini dilakukan dengan metode ceramah partisipatif, interaktif, dan dialogis. Sehingga peserta pelatihan dapat dengan mudah memahami dan menerapkannya.

\section{HASIL}

Hasil yang dicapai dari kegiatan pengabdian masyarakat ini adalah meningkatnya kemampuan para orang tua dalam mendampingi anak-anaknya selama pembelajaran daring sehigga para orang tua mampu membagi waktu antara pekerjaannya dan membantu mendampingi anaknya meskipun para orang tua sedikit kuwalahan dalam memerankan perannya sebagai orang tua dan sebagai guru dalam rumahnya. Selain tanggung jawab mendidik anak, orang tua dituntut mendampingi anak belajar daring di rumah sebagai ganti pembelajaran tatap muka. Dalam kondisi seperti saat ini, disadari atau tidak, para orang tua menjalankan peran ganda pendidikan. Pertama, peran utama orang tua. Kedua, peran tambahan orang tua. Peran tambahan ini muncul seiring pembatasan sosial. Belajar dan bekerja di rumah menjadi solusi yang tak terelakkan. Partisipasi orang tua diperlukan dalam proses sekolah online. Pendek kata orang tua adalah guru, mewakili sekolah, di rumah. Di mana mereka berperan mengadministrasikan pembelajaran dari tahap anak mengerjakan tugas, melaporkan tugas, hingga mengerjakan ujian daring.

Berdasarkan evaluasi dan simulasi pada pelatihan dari kegiatan pengabdian masyarakat dapat diketahui bahwa dengan adanya pelatihan maka peran orang tua dalam menciptakan pemanfaatan internet untuk pendidikan masih sangat jarang dilakukan. Selain itu, program pengabdian yang dipaparkan menambah wawasan bagi para orang tua bagaimana peran orang tua dan guru dalam membangun kebiasaan anak untuk memanfaatkan internet untuk pembelajaran masih belum dilakukan. Peran orang tua dan guru ini sangat penting, karena mereka adalah orang yang berhadapan langsung dengan anak-anak dilingkungan keluarga dan sekolah guru.

\section{KESIMPULAN}

Kegiatan pengabdian kepada masyarakat bermanfaat bagi orang tua sasaran karena setelah mengikuti kegiatan tersebut para orang tua lebih memahami pemanfaatan internet yang selama ini mereka jarang melakukannya. Sosialisasi tentang 
peran orang tua dalam pembelajaran daring sangat membantun para orang tua sehingga para orang tua akan lebih mudah dalam membantu anak-anaknya selama dalam pembelajaran daring. Hasil dari kegiatan pengabdian kepada masyarakat yang telah dilakukan yaitu orang tua harus berpartisipasi dalam menyampaikan kembali materi pembelajaran serta membuat anak memahami konsep yang diberikan guru secara online. Lalu orang tua akan membantu mereka dalam pengerjaan tugas jika terjadi kesulitan. Mereka dengan aktif menanyakan hal-hal yang belum mereka pahami. Mereka juga dengan bersemangat mencoba mengeksplorasi diri dalam mencari ide atau gagasan untuk dikembangkan dalam menghadapi berbagai masalah dalam masyarakat.

\section{DAFTAR PUSTAKA}

Cahana, Nana. 2020. Pembelajaran Daring dan Peran Ganda Orang tua. Kompasiana.

Cahyati, Nika. 2020. Peran Orang Tua Dalam Menerapkan Pembelajaran di Rumah Saat Pandemi Covid 19. Jurnal Golden Age, Universitas Hamzanwadi, 04(1).

Chalim, Saifuddin dkk. 2018.Peran Orang tua dan Guru dalam Membangun Internet sebagai Sumber Pembelajaran (The Role of Parents and Teachers in Building the Internet as a Source of Learning). Jurnal Penyuluhan, 14(1).

https://www.stit-alkifayahriau.ac.id/partisipasi-orang-tua-terhadap-pendidikan-anakselama-pembelajaran-daring/

https://id.theasianparent.com/peran-orangtua-belajar-daring

Yuhasriati, Jasmaniah, Budi Azhari, Aisyah Ma'Awiyah, Zulkifli, Syabuddin, Marwan Hamid, Hamidansyah, Muhammad Ridhwan, Hambali, Ilyas, and Samsul Bahri. 2020. "E-Learning as Connector among Education Institution in the 4th Industrial Revolution." in Journal of Physics: Conference Series. 